History

Education

Research

Journal
Bernhard, R. (2019) 'Using mixed methods to capture complexity in an empirical project about teachers' beliefs and history education in Austria'. History Education Research Journal, 16 (1): 63-73. DOI https://doi.org/10.18546/HERJ.16.1.06

\title{
Using mixed methods to capture complexity in an empirical project about teachers' beliefs and history education in Austria
}

\author{
Roland Bernhard* - University of Oxford, UK
}

\begin{abstract}
In international methodological literature, and in the literature about research in education in general, mixed-methods research (MMR) has been identifiedasa means to get deeper and broader insights, and to validate findings in research projects. Nevertheless, so far there has not been much reflection upon mixed methods in the history education research community. In this article, some advantages of the concept will be presented, drawing on international methodological literature. It will ask how these advantages may be used in research projects in history education to get richer findings. This paper will present an Austrian mixedmethods project, and will reflect upon the experience of using qualitative and quantitative methodology in it. The Competence and Academic Orientation in History Textbooks (CAOHT) and Epistemic Beliefs of Austrian History Teachers after the Paradigm Shift to Historical Thinking (EBAHT) projects researched the beliefs of history teachers and history teaching nearly a decade after the reform that changed the Austrian history curriculum from content orientation to domainspecific competence orientation (historical thinking). Sequential qualitativequantitative triangulation study has made it possible to capture some of the complexity of such an undertaking, more than would have been possible using a mono-method design. To base a survey on a previous qualitative study can help to interpret the context of the statistical results, put into perspective the answers and see relations that are difficult to detect when relying on a mono-method design. Also, when there is corroborating evidence from qualitative and quantitative data, conclusions may be drawn with more confidence, and generalization of qualitative findings becomes possible.
\end{abstract}

Keywords: triangulation; interviews; questionnaire; teachers' beliefs; curriculum

\section{Introduction}

Mixed-methods research (MMR) - the collection, analysis and integration of both qualitative and quantitative data in the study of one social phenomenon - is a rapidly developing field of social science methodology (Kelle, 2006: 293). After fierce 'paradigm wars' (see Kelle et al. in this special issue; Gage, 1989) between the methodological traditions of qualitative and quantitative research, in the last decades, the 'third methodological movement' (Gorard and Taylor, 2004: 1-12), based on the philosophy of pragmatism, has become increasingly important in different disciplines (see, for example, Doyle et al., 2009; Burke Johnson and Onwuegbuzie, 2004; Bergman, 2008; Brannen, 2005) and also in educational research (Sammons, 2010; Riazi and Candlin, 2014). It has been argued that, generally speaking, quantitative and qualitative 
methods 'are nearly always more powerful when used in combination than in isolation' (Gorard and Taylor, 2004: 4) in a research project. Mixed methods has been called 'the "hot topic" in current social sciences' (Flick, 2017: 1).

In education research, it has been argued that linking stories (qualitative) and statistics (quantitative) is likely to offer more powerful explanations and a better understanding, and thus has the potential to be of greater practical relevance and accessibility to practitioners and policymakers (Sammons, 2010: 699). In this sense, MMR is said often to have greater impact, since figures (quantitative) can be persuasive to policymakers, whereas stories (qualitative) can be more easily remembered and repeated by them for illustrative purposes (Gorard and Taylor, 2004: 7). Gorard and Taylor (2004: 2) point out, in relation to education research, the 'pressing need ... to overcome any rigid methods identities, supported by terms like "qualitative" and "quantitative", and to learn more about a wider range of methods as users, consumers and critics of each others' research'. It has also been recognized that, in education journals, research reports with a mixed-methods approach are in the ascendant (Niglas, 2004, cited in Riazi and Candlin, 2014; see also Alise and Teddlie, 2010). Flick (2017: 1) points out that the mixed-methods 'boom' has led to expectations by funding agencies that good research proposals in many areas need to include a combination of quantitative and qualitative methods.

However, as we argued in the introductory article of this special edition, within the history education research community, there has not been much theoretical reflection about, or conscious practical application of, mixed-methods or triangulation designs, although many studies have used qualitative and quantitative approaches or triangulation to study phenomena in history education (see Kelle et al. in this special edition; also see, for example, Jeismann et al., 1987; Evans, 1989, 1990; Von Borries et al., 2005; Maggioni, 2010; Harris and Burn, 2016). An overview of some mixedmethods studies was recently published by Epstein and Salinas (2018). Also, Prinz and Thünemann (2016) are an exception concerning theoretical reflection about mixed methods in history education research.

This article discusses the CAOHT project (Competence and Academic Orientation in History Textbooks) ${ }^{1}$ that was conducted in Salzburg, Austria (2015-18) and was followed up at the University of Oxford, UK by the author (2018-19) with the EBAHT project (Epistemic Beliefs of Austrian History Teachers after the Paradigm Shift to Historical Thinking). ${ }^{2}$ The article reflects upon how the combination of both general numerical findings and specific cases enriched this project and helped to capture some complexity by 'mutually illuminating' (Bryman, 2007: 8) findings of the qualitative and the quantitative strand. The primary purpose of this paper is to discuss the application of mixed methods in the study, and to give some examples of how mixed methods can be a way of dealing with complexity in history education research.

\section{Theoretical framework}

In the CAOHT/EBAHT project, the central focus was on the question of how Austrian history teachers use textbooks in their teaching practice, and the role that historical thinking plays in this context. The paradigm shift in history education research from content orientation to historical thinking, with its focus on domain-specific competences (Körber and Meyer-Hamme, 2015; Seixas and Morton, 2013; Wineburg, 2001) has informed the Austrian history curriculum since 2008 (Kühberger, 2009). Today, the development of historical thinking skills is the primary goal of history education - at least theoretically. However, as Hattie (2003: 2) pointed out, the crucial question 
is how 'the person who gently closes the classroom door and performs the teaching act' interprets and enacts the curriculum and new policies. In order to determine the role that historical thinking plays in teachers' attitudes and lessons, it is necessary to research not only their actions, but also their beliefs. After Evans $(1989,1990)$ pioneered research into the beliefs of history teachers, the topic has become an increasingly important area in international research in America, Africa and Europe, especially recently (see Litten, 2017; Namamba and Rao, 2016; Voet and De Wever, 2016; Nitsche, 2016; VanSledright and Reddy, 2014; Oppong and Quan-Baffour, 2014; Fenn, 2013, among many others). However, the beliefs of Austrian history teachers and the impact of the curriculum reform of 2008 have not been extensively empirically researched; only Pichler (2016) provides some initial insights. Within the CAOHT/EBAHT project, this gap was closed using MMR.

Researching history education and the beliefs of history teachers is a complicated undertaking. In such studies, scholars repeatedly report inconsistency in teachers' answers, and especially that the quantitative results were at times difficult to interpret (Daumüller, 2012; Messner and Buff, 2007; VanSledright and Reddy, 2014; Wansink et al., 2017). It has been argued in methodological literature that the flexibility allowed by mixed-methods designs can be particularly suited to the study of complex educational topics, in order to be able to unpick the complexities and finer detail entangled within social and educational experiences (Sammons et al., 2011). Mixed methods have been described as a way to capture the complexity with which researchers have to deal in educational sciences (McKim, 2017: 213; Ponce and Pagán-Maldonado, 2015: 132). In 2007, a study by Burke Johnson et al. was published examining the criteria that leaders in the field considered important for defining MMR. They emailed 36 leading researchers and asked them to share their current definitions of MMR. Based on the answers, the authors arrived at the following definition:

Mixed Methods research is the type of research in which a researcher or team of researchers combines elements of qualitative and quantitative research approaches (e.g. use of qualitative and quantitative viewpoints, data collection, analysis, inference techniques), for the broad purposes of breadth and depth of understanding and corroboration. (Burke Johnson et al., 2007: 123; emphasis added)

According to this definition, the benefits of mixing methodologies are mainly: (1) breadth and depth of understanding; and (2) corroboration of findings. The debate over breadth or depth is whether it is more beneficial to gather minimal data on an extensive cohort or to gather detailed, comprehensive data on a small sample.

Normally, a large number of participants adds 'breadth' to a study, since with such data it is possible to provide information from many different perspectives. If only a few participants are involved, the focus is on an in-depth understanding, whereas such an understanding is often difficult to reach with a large sample. Depth in this sense means the density of the contextual information of cases, and is associated with the qualitative paradigm, whereas breadth is associated with the quantitative paradigm. For the researchers who were surveyed in the study by Burke Johnson et al. (2007: 122), MMR enables them to provide a 'fuller picture' of the object of study, and makes it possible to 'enhance description'. McKim (2017: 213) expresses this in terms of a 'more balanced perspective'. The findings that a research project with a mixed-methods design can provide are 'more comprehensive, more multi-perspective and thus more complete' (in German: 'umfangreicher, mehrperspektivischer und somit vollständiger') (Kuckartz, 2014: 54). 
With respect to corroboration, Burke Johnson et al. (2007: 122) point out that mixed methods 'validate and explicate findings from another approach and produce more comprehensive, internally consistent, and valid findings'. It is possible to combine the strengths and minimize the weaknesses of each methodology (McKim, 2017: 213). MMR therefore is said to 'provide more elaborated understanding and greater confidence in conclusions' (Burke Johnson et al., 2007: 122). It is a way to be 'certain of findings' (McKim, 2017: 214), since it makes it possible to 'handle threats to validity' better (Burke Johnson et al., 2007: 122). Gorard and Taylor (2004: 7) argue that 'research claims are stronger when based on a variety of methods'. In a recent publication, the German scholar Kuckartz (2014: 54) pointed out that statistical relations (quantitative) may be explained more comprehensively if they are described by example, verbal data, pictures or films (qualitative). Quantitative data are enriched by a detailed indepth view, the singular case and the personal experiences of subjects. On the other hand, qualitative data become more powerful when numerical information is added: the chance to generalize qualitative research results is greater. Kelle (2006: 307) noted that a QUAL $\rightarrow$ QUAN study (sequential qualitative-quantitative triangulation) might overcome both the problems of the limited transferability (generalizability) of findings from qualitative research, and also the weakness of quantitative studies, because of their 'lack of sociocultural "local" knowledge', which might seduce researchers into applying concepts that 'fail to grasp the most relevant phenomena in the field' being investigated. When a research process starts with a qualitative study, the local knowledge gained may help to develop theoretical concepts and hypotheses for standardized research instruments that are able to uncover relevant phenomena.

As is clear from the previous section, there is no lack of confidence about this concept in the mixed-methods research community. Only occasionally are the optimistic voices disturbed, for example by the call for 'unmixing mixed methods research' (Sandelowski, 2014), or by researchers who argue that the community is following 'mantras and myths', pointing out that there is 'a slowly but continuously intensifying disenchantment of MMR' (Flick, 2017: 1). Notwithstanding these isolated criticisms, this article will reflect upon how, in a project in the area of history education research, insights were gained that probably would not have been possible to obtain using a mono-method approach.

\section{Research design of the CAOHT/EBAHT project}

The literature concerning mixed methods (Guest, 2013) asserts the value of a diagram illustrating the various qualitative and quantitative research components and phases. Figure 1 depicts the research design of the CAOHT/EBAHT project.

In the first proposal to receive funding for the $\mathrm{CAOHT}$ project sent to the Austrian Science Fund, only a quantitative survey was planned to research the beliefs held by teachers with respect to competence orientation, historical thinking, textbook use and so on. One reviewer pointed out that the mono-method approach was a weakness, and suggested a change of design to an MMR study. Since the generous grant of $€ 286,000$ was received only after modification of the research design, this example might be a confirmation of Flick (2017: 1), who noted that research proposals with a mixed-methods design are currently more likely to be funded than others. The design was changed to a sequential qualitative-quantitative triangulation. It is a characteristic of such a sequential design that 'questions or procedures of one strand emerge from, or are dependent on, the previous strand' (Teddlie and Sammons, 2010: 118). Thus, mixing methodology occurs across chronological phases. In the case of the CAOHT/ 
EBAHT project, the qualitative study was conducted first, and the quantitative survey study emerged from the qualitative interview and observation results (see Figure 1).

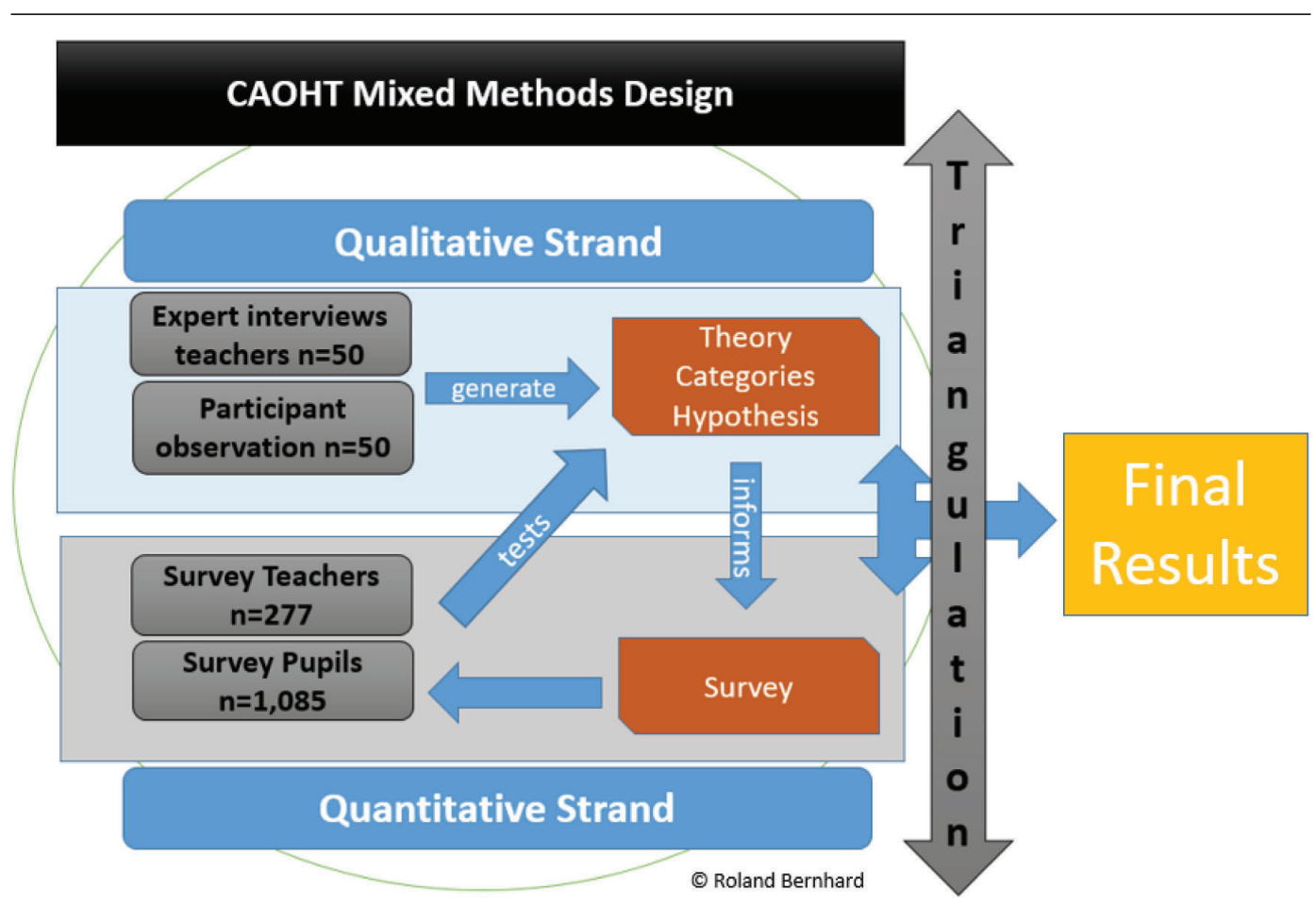

Figure 1: Sequential qualitative-quantitative triangulation (mixed methods)

Qualitative data were collected in 26 different schools in Vienna (Gymnasium and Hauptschulen/Neue Mittelschulen). Teachers from these schools were recruited on a voluntary basis with the help of school inspectors, principals and colleagues from the University of Education, Vienna. There was a high diversity in the sample of schools and in the sample of teachers. Fifty history lessons were observed and audiotaped (2,430 minutes), and expert interviews with 50 history teachers were conducted (semi-structured, face-to-face; average interview time: 40 minutes) according to the method described in Bogner et al. (2009). The interviews and the observations led to rich textual data that were analysed using MaxQDA. This analysis provided the foundation to construct the quantitative survey (see Bernhard, 2018a). In the next step, the hypotheses generated were tested by a survey study with teachers $(n=277)$ and students $(n=1,085)$ in three different states in Austria (Vienna, Styria and Salzburg). The quantitative data are currently being evaluated to investigate which qualitative findings can be generalized quantitatively for Austria. In other words, the qualitative study helped to identify the core issues and to develop the theoretical concepts and hypotheses that were further examined in the subsequent quantitative study. As Kelle (2006: 307) points out, in such a triangulation design, the subsequent quantitative study is then 'carried out with the goal of finding out whether concepts relevant in a comparable small number of cases describe and explain social phenomena in a greater domain accordingly'. The overview of the results from both the qualitative and the quantitative strands will provide the final results. 


\section{Using MMR in the CAOHT/EBAHT project: Depth and breadth of understanding}

As discussed, in the literature about mixed methods, it is argued that by studying one social phenomenon with different methodologies, it is possible to get a deeper and broader understanding of the object of study. With respect to the beliefs that history teachers hold about competence-based history education, our conclusion is that this was also the case in the CAOHT/EBAHT project. Since it was a central aim of the study to determine how the shift to domain-specific competence orientation affected the beliefs of history teachers and the practice of history teaching, the term 'competence orientation' is central to the study. In the qualitative interviews, however, we found that the understanding of the concept 'competence orientation' by teachers was, to a great degree, different from the understanding in history education research and in the Austrian history curriculum (see Bernhard and Kühberger, 2019). According to the Austrian curriculum, the domain-specific competences of historical thinking are:

- skills of deconstruction of narrative (deconstruction competence)

- reconstruction of history from sources (reconstruction competence)

- being able to incorporate insights from dealing with history into one's own life in the present and for the future (orientation competence)

- asking questions about the past (competence of questioning)

- a competence of notion and structures that is difficult to translate (Sachkompetenz) (Kühberger, 2009).

Nevertheless, in the qualitative interviews it became clear that teachers associate very different kinds of things with the terms 'competences' and 'competence orientation' in history, but very seldom domain-specific concepts. If we had used a quantitative survey only, this probably would have been difficult to find out, and it might have biased the results. When Austrian history teachers were asked which competences are important in their history teaching, general competences such as reading, digital competences, self-competence or social competence were mentioned very frequently. The answer of interviewed teacher N22 is typical:

Interviewer: What are the competences that you think could be fostered in history education somehow?

Teacher N22: Well, this depends on the arrangement, social learning, yes. Social competence plays an important role, yes. There are so many competences in it, from the competence to speak one's own language to the competence in foreign languages, only because of the technical jargon. Well, I believe, there is much competence training, also mathematical competences, depends...

Interviewer: Other competences that play a role in your teaching, in your history teaching?

Teacher N22: Well, yes, open learning. They often have to search something on the internet. Yes, every now and then we do it.

In this interview quotation, nothing can be found that is domain specific to history, and this reflects how most of the teachers answered when asked about competence orientation in history teaching. Competences were extensively talked about in the 50 interviews: an analysis of all the protocols shows that the word 'competence' was mentioned more than a thousand times. A closer look at all the mentions reveals 
that one of the domain-specific competences that is to be found in the Austrian history curriculum of 2008 was mentioned only 18 times - less than 2 per cent of all mentions. This finding from interviews has important implications for the quantitative study: if we had not known before the quantitative study that the understanding of competence orientation is not domain specific in most cases, we might have asked in the survey: 'How important are historical competences to you in your teaching?' Teachers may have thought about their construct of competences, and answered: 'Very important' or 'Not important at all'. But how would we have interpreted the answers of the teachers? Because of the understanding of the teachers, the results would not have revealed much about their attitudes towards historical thinking competences, which was one of the main focuses of the study.

In the literature, it is stated that items of a questionnaire must capture the information that is intended, so as to achieve reliability and validity (Porst, 2014: 17), which means that a construct has to be understood in the field by the subjects in the same way that researchers understand it. Even though a construct seems very clear to researchers, a central factor for content validity of a question in a survey (Faulbaum et al., 2009: 48) is how the subjects interpret it (ibid.: 63). Therefore, an important rule in survey construction is to use unambiguous terms that can be understood by all subjects in the same way (Porst, 2014: 99).

It was in this way that the qualitative study helped us to deepen our knowledge about the understanding of teachers, and to construct the survey in such a way that this aspect was taken into consideration. For example, an item was introduced that asked how prepared teachers feel with respect to historical competence orientation. The answers to this question also provide corroborating evidence with respect to the qualitative results, since in the survey more than 42 per cent of all teachers said that they had not dealt much with questions about historical competence orientation, and another 36.7 per cent chose the middle category ('partly'), whereas only about 20 per cent of the teachers answered 'fully' or 'fairly fully'. In this case, qualitative and quantitative findings were obviously mutually informative and helped to increase validity.

Another aspect relating to depth of understanding was about how history lessons are being conducted. In the literature, it is stated that quantitative designs do not normally reveal anything 'really new', because such designs are about testing hypotheses that have been constructed beforehand. This also means that when a hypothesis is tested and not falsified, strictly speaking, existing knowledge is extended and proved to be representative. So, by using qualitative methodology before a quantitative survey, empirical phenomena and relations may be seen that would not have been detected using only a survey, because they were invisible during its construction. In our project, using qualitative participant observation before the survey study made it possible to describe forms of textbook work that had not been described in the literature so far and that would not have been possible to 'see' using only a quantitative questionnaire (see Bernhard, 2018a: 49-50).

\section{Using MMR in the CAOHT/EBAHT project: Corroboration}

In the CAOHT/EBAHT project, applying mixed methods also helped to corroborate findings. In the course of the participant observations and in the interviews, it became apparent that history textbooks are used extensively in history lessons in Austria, and in many different ways. Based on the qualitative strand, it was possible to describe ways in which textbooks are used in Austrian history classrooms (see Bernhard, 2018b). 
Nevertheless, from a qualitative non-standardized study in Vienna, it is difficult to draw conclusions that would apply to the whole country. However, in the quantitative phase of the study, the validity range of our qualitative findings was tested through the survey. We investigated whether the quantitative data also indicate the equal dominance of textbook-focused teaching and learning in history lessons in Austria as a whole. The quantitative results are to be published in Bernhard et al. (forthcoming), so they will not be reported here. One thing can be said at this stage, however - the qualitative findings can, to a high degree, be correlated with the quantitative data. By combining four kinds of data (from participant observation, interviews, and the surveys of students and teachers), it will be possible to provide evidence about the nature of the extensive use of textbooks in history teaching in Austria.

To mention a related example from the $\mathrm{CAOHT/EBAHT} \mathrm{project,} \mathrm{in} \mathrm{the} \mathrm{interviews,}$ and also in informal talks with teachers before and after participant observation (informal talks were protocolled in a field diary), it became clear that teachers use textbooks as inspiration, models or templates for worksheets that they construct, and that they distribute copies made from textbooks as worksheets. Teacher A16 said:

Yes, I always make worksheets about the content. I really do it, I do it step by step, yes, also the content from the textbooks, but I make my own worksheets and I summarize the information from the textbook and I add my own things.

If we had not taken into consideration that textbooks are frequently the basis for worksheets, it is possible that this aspect of the use of textbooks in history lessons would not have been detected. When responding to a survey item of the kind, 'Which resources do you use in your history lessons and for how much time: worksheets, textbooks, internet?', many teachers would have revealed that they use worksheets very often, but their answers could have been misinterpreted in relation to the textbook as the key medium. Since we found the relationship between textbooks and worksheets to be strong in the qualitative data, this could be taken into consideration in the construction of the survey, where it was also included as an item:

When I create worksheets, I let myself be inspired by history textbooks (five-point Likert scale: 'very often' to 'never').

The quantitative data (survey teachers, $n=277$ ) could provide corroborating evidence, since only 6.9 per cent of the respondents said that they 'never' do so; 43.4 per cent said that they do it 'very often' or 'often' (15.7 per cent 'very often'; 27.7 per cent 'often'); 29.9 per cent answered 'sometimes'; and 19.7 per cent said 'seldom'. In this way, the qualitative study not only inspired the survey, but the overview of the two kinds of data provided corroboration and made generalization possible.

\section{Discussion and conclusion}

In methodological literature, the third paradigm MMR is discussed as a very powerful means to add breadth, depth and corroboration to a research study. History education research deals with complex constructs. In this sense, MMR is conceived as offering ways to incorporate such complexity and to compensate for the methodological weaknesses of partial approaches. This article has reflected upon how some of the alleged benefits of MMR were experienced in a study about history education and the beliefs of history teachers in Austria. We have the impression that, in general, the application of mixed methods helped to capture some of the complexity of 
researching historical thinking approaches in history teaching better than would have been possible using a mono-method design. To base a survey on a previous qualitative study can help to interpret the context of the statistical results and put the answers into perspective. When there is corroborating evidence from qualitative and quantitative data, as was the case with respect to the frequency and intensity of textbook work and with some aspects of using worksheets, this can help conclusions to be drawn with more confidence.

\section{Notes on the contributor}

Roland Bernhard is a visiting research fellow at the Department of Education at the University of Oxford (UK), and a postdoctoral researcher and lecturer in history and civic education at the University of Salzburg (Austria). He has taught history and civic education and cultural studies at several universities in Austria (Graz, Innsbruck, Salzburg), and has published a range of books and articles, mainly in the area of history education. He worked for several years as a teacher in schools.

\section{Notes}

1 The CAOHT project was funded by the Austrian Science Fund (P 27859-G22).

2 The EBAHT project was funded by the Habilitation Forum for Subject-focused Didactics and Classroom Research, University of Graz.

\section{References}

Alise, M.A. and Teddlie, C. (2010) 'A continuation of the paradigm wars? Prevalence rates of methodological approaches across the social/behavioral sciences'. Journal of Mixed Methods Research, 4 (2), 103-26.

Bergman, M.M. (ed.) (2008) Advances in Mixed Methods Research: Theories and applications. London: SAGE Publications.

Bernhard, R. (2018a) 'Fragebogenentwicklung anhand qualitativer Daten in einem MixedMethods-Research-Design: Eine geschichtsdidaktische Perspektive zu historischem Denken und Schulbuchnutzung'. In Bramann, C., Kühberger, C. and Bernhard, R. (eds) Historisch Denken lernen mit Schulbüchern. Schwalbach am Taunus: Wochenschau Verlag, 37-62.

Bernhard, R. (2018b) 'Teaching to think historically using textbooks: Insights for initial teacher education drawn from a qualitative empirical study in Austria'. Educatio Siglo XXI, 36 (1), 41-58.

Bernhard, R., Bramann, C. and Kühberger, C. (forthcoming) 'Verwendung des Geschichtsschulbuches durch Schüler/innen und Lehrer/innen. Empirische Hauptergebnisse des Mixed-Methods-Projektes CAOHT' (in preparation).

Bernhard, R. and Kühberger, C. (2019) 'Domänen(un)spezifisch: Empirische Befunde zum Kompetenzverständnis von Geschichtslehrpersonen'. In Waldis, M. and Ziegler, B. (eds) Forschungswerkstatt Geschichtsdidaktik 17. Bern: Hep verlag.

Bogner, A., Littig, B. and Menz, W. (eds) (2009) Interviewing Experts. Basingstoke: Palgrave Macmillan.

Brannen, J. (2005) 'Mixing methods: The entry of qualitative and quantitative approaches into the research process'. International Journal of Social Research Methodology, 8 (3), 173-84.

Bryman, A. (2007) 'The research question in social research: What is its role?'. International Journal of Social Research Methodology, 10 (1), 5-20.

Burke Johnson, R. and Onwuegbuzie, A.J. (2004) 'Mixed methods research: A research paradigm whose time has come'. Educational Researcher, 33 (7), 14-26.

Burke Johnson, R., Onwuegbuzie, A.J. and Turner, L.A. (2007) 'Toward a definition of mixed methods research'. Journal of Mixed Methods Research, 1 (2), 112-33.

Daumüller, M. (2012) 'Einstellungen und Haltungen von Fachlehrerinnen und Fachlehrern'. In Barricelli, M. and Lücke, M. (eds) Handbuch Praxis des Geschichtsunterrichts (Vol. 2). Schwalbach am Taunus: Wochenschau Verlag, 370-85.

Doyle, L., Brady, A.-M. and Byrne, G. (2009) 'An overview of mixed methods research'. Journal of Research in Nursing, 14 (2), 175-85. 
Epstein, T. and Salinas, C.S. (2018) 'Research methodologies in history education'. In Metzger, S.A. and McArthur Harris, L. (eds) The Wiley International Handbook of History Teaching and Learning. Hoboken, NJ: Wiley-Blackwell, 61-91.

Evans, R.W. (1989) 'Teacher conceptions of history'. Theory and Research in Social Education, 17 (3), 210-40.

Evans, R.W. (1990) 'Teacher conceptions of history revisited: Ideology, curriculum, and student belief'. Theory and Research in Social Education, 18 (2), 101-38.

Faulbaum, F., Prüfer, P. and Rexroth, M. (2009) Was ist eine gute Frage? Die systematische Evaluation der Fragenqualität. Wiesbaden: VS Verlag für Sozialwissenschaften.

Fenn, M. (2013) 'Konstruktivistisches Geschichtsverständnis im Unterricht fördern: Studierende ändern ihr Lehrverhalten von einseitig instruktional in problemorientiert'. In Hodel, J., Waldis, M. and Ziegler, B. (eds) Forschungswerkstatt Geschichtsdidaktik 12: Beiträge zur Tagung "geschichtsdidaktik empirisch 12". Bern: Hep, 60-71.

Flick, U. (2017) 'Mantras and myths: The disenchantment of mixed-methods research and revisiting triangulation as a perspective'. Qualitative Inquiry, 23 (1), 46-57.

Gage, N.L. (1989) 'The paradigm wars and their aftermath: A "historical" sketch of research on teaching since 1989'. Educational Researcher, 18 (7), 4-10.

Gorard, S. and Taylor, C. (2004) Combining Methods in Educational and Social Research. Maidenhead: Open University Press.

Guest, G. (2013) 'Describing mixed methods research: An alternative to typologies'. Journal of Mixed Methods Research, 7 (2), 141-51.

Harris, R. and Burn, K. (2016) 'English history teachers' views on what substantive content young people should be taught'. Journal of Curriculum Studies, 48 (4), 518-46.

Hattie J. (2003) 'Teachers make a difference: What is the research evidence?' Paper presented at the 'Building Teacher Quality: What does the research tell us' ACER Research Conference, Melbourne, Australia, 2003. Online. https://research.acer.edu.au/cgi/viewcontent.cgi?article=100 3\&context=research_conference_2003 (accessed 28 March 2018).

Jeismann, K.-E., Kosthorst, E., Schäfer, B., Schlöder, B., Teppe, K. and Wasna, M. (1987) Die Teilung Deutschlands als Problem des Geschichtsbewußtseins: Eine empirische Untersuchung über Wirkungen von Geschichtsunterricht auf historische Vorstellungen und politische Urteile. Paderborn: Schöningh.

Kelle, U. (2006) 'Combining qualitative and quantitative methods in research practice: Purposes and advantages'. Qualitative Research in Psychology, 3 (4), 293-311.

Körber, A. and Meyer-Hamme, J. (2015) 'Historical thinking, competencies, and their measurement: Challenges and approaches'. In Ercikan, K. and Seixas, P. (eds) New Directions in Assessing Historical Thinking. New York: Routledge, 89-101.

Kuckartz, U. (2014) Mixed Methods: Methodologie, Forschungsdesigns und Analyseverfahren. Wiesbaden: Springer.

Kühberger, C. (2009) Kompetenzorientiertes historisches und politisches Lernen: Methodische und didaktische Annäherungen für Geschichte, Sozialkunde und Politische Bildung. Innsbruck: StudienVerlag.

Litten, K. (2017) Wie planen Geschichtslehrkräfte ihren Unterricht? Eine empirische Untersuchung der Unterrichtsvorbereitung von Geschichtslehrpersonen an Gymnasien und Hauptschulen. Göttingen: Vandenhoeck und Ruprecht.

Maggioni, L. (2010) 'Studying Epistemic Cognition in the History Classroom: Cases of teaching and learning to think historically'. Unpublished PhD thesis, University of Maryland.

McKim, C.A. (2017) 'The value of mixed methods research: A mixed methods study'. Journal of Mixed Methods Research, 11 (2), 202-22.

Messner H. and Buff, A. (2007) 'Lehrerwissen und Lehrerhandeln im Geschichtsunterricht didaktische Überzeugungen und Unterrichtsgestaltung'. In Gautschi, P., Moser, D., Reusser, K. and Wiher, P. (eds) Geschichtsunterricht heute: Eine empirische Analyse ausgewählter Aspekte. Bern: Hep verlag. 143-75.

Namamba, A. and Rao, C. (2016) 'Teachers' beliefs about history and instructional approaches: A survey of secondary school teachers in Kigoma Municipality, Tanzania'. International Journal of Education and Research, 4 (8), 203-20.

Niglas, K. (2004) 'The combined use of qualitative and quantitative methods in educational research'. Unpublished PhD thesis, Tallinn Pedagogical University.

Nitsche, M. (2016) 'Geschichtstheoretische und -didaktische Überzeugungen von Lehrpersonen: Begriffliche und empirische Annäherungen an ein Fallbeispiel'. In Buchsteiner, M. and Nitsche, M. (eds) Historisches Erzählen und Lernen: Historische, theoretische, empirische und pragmatische Erkundungen. Wiesbaden: Springer, 159-96. 
Oppong, C.A. and Quan-Baffour, K.P. (2014) 'The nature of historical facts: History teachers' conception of it'. Journal of Education and Practice, 5 (29), 136-43.

Pichler, C. (2016) 'Lehrer/innen und Kompetenzorientierung im Geschichtsunterricht und im Unterricht aus Politischer Bildung'. Erziehung und Unterricht, 166 (3-4), 286-94.

Ponce, O.A. and Pagán-Maldonado, N. (2015) 'Mixed methods research in education: Capturing the complexity of the profession'. International Journal of Educational Excellence, 1 (1), 111-35.

Porst, R. (2014) Fragebogen: Ein Arbeitsbuch. 4th ed. Wiesbaden: Springer.

Prinz, D. and Thünemann, H. (2016) 'Mixed-Methods-Ansätze in der empirischen Schul- und Unterrichtsforschung: Möglichkeiten und Grenzen für die Geschichtsdidaktik'. In Thünemann, H. and Zülsdorf-Kersting, M. (eds) Methoden geschichtsdidaktischer Unterrichtsforschung. Schwalbach am Taunus: Wochenschau Verlag, 229-53.

Riazi, A.M. and Candlin, C.N. (2014) 'Mixed-methods research in language teaching and learning: Opportunities, issues and challenges'. Language Teaching, 47 (2), 135-73.

Sammons, P. (2010) 'The contribution of mixed methods to recent research on educational effectiveness'. In Tashakkori, A. and Teddlie, C. (eds) Sage Handbook of Mixed Methods in Social and Behavioural Research. Thousand Oaks, CA: Sage, 697-723.

Sammons, P., Gu, Q., Day, C. and Ko, J. (2011) 'Exploring the impact of school leadership on pupil outcomes: Results from a study of academically improved and effective schools in England'. International Journal of Educational Management, 25 (1), 83-101.

Sandelowski, M. (2014) 'Unmixing mixed-methods research'. Research in Nursing and Health, 37 (1), 3-8.

Seixas, P. and Morton, T. (2013) The Big Six Historical Thinking Concepts. Toronto: Nelson Education.

Teddlie, C. and Sammons, P. (2010) 'Applications of mixed methods to the field of educational effectiveness research'. In Creemers, B.P.M., Kyriakides, L. and Sammons, P. (eds) Methodological Advances in Educational Effectiveness Research. London: Routledge, 115-52.

VanSledright, B. and Reddy, K. (2014) 'Changing epistemic beliefs? An exploratory study of cognition among prospective history teachers'. Revista Tempo e Argumento, 6 (11), 28-68.

Voet, M. and De Wever, B (2016) 'History teachers' conceptions of inquiry-based learning, beliefs about the nature of history, and their relation to the classroom context'. Teaching and Teacher Education, 55, 57-67.

Von Borries, B., Fischer, C., Leutner-Ramme, S. and Meyer-Hamme, J. (2005) Schulbuchverständnis, Richtlinienbenutzung und Reflexionsprozesse im Geschichtsunterricht: Eine qualitativquantitative Schüler- und Lehrerbefragung im Deutschsprachigen Bildungswesen 2002. Bayerische Studien zur Geschichtsdidaktik, Vol. 9. Neuried: Ars Una.

Wansink, B., Akkerman, S., Vermunt, J., Haenen, J. and Wubbels, T. (2017) 'Epistemological tensions in prospective Dutch history teachers' beliefs about the objectives of secondary education'. The Journal of Social Studies Research, 41 (1), 11-24.

Wineburg, S. (2001) Historical Thinking and Other Unnatural Acts: Charting the future of teaching the past. Philadelphia: Temple University Press. 